\title{
Mortality and morbidity of extremely low birth weight infants in Hong Kong, 2010-2017: a single- centre review
}

\author{
KL Hon *, Sharon Liu, Joey CY Chow, Kathy YC Tsang, Hugh S Lam, KW So, Yvonne KY Cheng, \\ Alexander KC Leung, William Wong
}

\section{A B S T R A C T}

Background: Extremely low birth weight (ELBW) infants exhibit high rates of mortality and morbidity. We retrospectively assessed factors associated with mortality and morbidity among ELBW infants.

Methods: Perinatal demographic data were reviewed for all ELBW infants born between 2010 and 2017 at a tertiary neonatal unit.

Results: For non-survivors (21\% ofELBW infants) and survivors, the median gestational ages were 24.1 and 26.2 weeks, respectively, and median birth weights were $650 \mathrm{~g}$ and $780 \mathrm{~g}$, respectively (all $\mathrm{P}<0.001$ ). Regression analyses showed that non-survival was positively associated with lower gestational age (adjusted odds ratio $[\mathrm{aOR}]=6.71$ for every 1 -week decrease; 95\% confidence interval $[\mathrm{CI}]=1.73$ 26.00; $\mathrm{P}=0.006)$ and grade 3 or 4 intraventricular haemorrhage $\quad(\mathrm{aOR}=29.23 ; \quad 95 \% \quad \mathrm{CI}=1.39-613.84$; $\mathrm{P}=0.030$ ); non-survival was negatively associated with the presence of bronchopulmonary dysplasia $(\mathrm{aOR}=0.01 ; 95 \% \mathrm{CI}=<0.001-0.23 ; \mathrm{P}=0.005)$; length of neonatal intensive care unit stay for survivors was positively associated with the presence of necrotising enterocolitis (B-coefficient $=89.60 ; 95 \% \mathrm{CI}=43.86$ 135.34; $\mathrm{P}<0.001)$; and length of hospital stay for survivors was positively associated with the presence of necrotising enterocolitis (B-coefficient $=2.08$; $95 \%$ $\mathrm{CI}=0.43-3.73 ; \mathrm{P}=0.015)$ and a low Apgar score at 1 minute $(\mathrm{B}$-coefficient $=-0.63 ; 95 \% \mathrm{CI}=-1.04$ to

Conclusion: Extremely low birth weight infants exhibited significant mortality and morbidity; there was no survival prior to 23.6 weeks' gestation or below $550 \mathrm{~g}$ birth weight. The presence of grade 3 or 4 intraventricular haemorrhage was independently associated with non-survival. Survivors were significantly more likely to exhibit bronchopulmonary dysplasia; survivors with necrotising enterocolitis were more likely to require longer stays in the neonatal intensive care unit and in hospital.

Hong Kong Med J 2018;24:460-5

DOI: 10.12809/hkmj177181

${ }^{1} \mathrm{KL} \mathrm{Hon} \mathrm{*}, \mathrm{MB}, \mathrm{BS}, \mathrm{MD}$

${ }^{2} S$ Liu, MB, ChB

${ }^{2} \mathrm{JCY}$ Chow, MB, ChB

${ }^{1} \mathrm{KYC}$ Tsang, MPhil

${ }^{1} \mathrm{HS}$ Lam, MBBChir, MD

${ }^{3} \mathrm{KW}$ So, MB, BS, MRCP

${ }^{4}$ YKY Cheng, MB, ChB, MRCOG

${ }^{5}$ AKC Leung, MB, BS, FRCPC

${ }^{1}$ W Wong, MB, BS

Department of Paediatrics, The Chinese University of Hong Kong, Shatin, Hong Kong

2 Faculty of Medicine, The Chinese University of Hong Kong, Shatin, Hong Kong

${ }^{3}$ Department of Paediatrics, Prince of Wales Hospital, Shatin, Hong Kong

${ }^{4}$ Department of Obstetrics and Gynaecology, The Chinese University of Hong Kong, Shatin, Hong Kong

${ }^{5}$ Department of Pediatrics, University of Calgary, Canada

* Corresponding author: ehon@hotmail.com

New knowledge added by this study

- Extremely low birth weight infants in Hong Kong showed significant mortality and morbidity: there was no survival prior to 23.6 weeks' gestation or below $550 \mathrm{~g}$ birth weight in this series.

- The presence of grade 3 or 4 intraventricular haemorrhage was independently associated with non-survival.

- Survivors were significantly more likely to exhibit bronchopulmonary dysplasia.

- Survivors with necrotising enterocolitis were significantly more likely to require longer stays in both the neonatal intensive care unit and hospital.

Implications for clinical practice or policy

- Parents in Hong Kong with extremely low birth weight infants should be counselled regarding expectations for infant survival and associated complications.

- Hong Kong hospitals can modify their practices to support an increased rate of survival and decreased rate of complications among extremely low birth weight infants.

- These findings may guide future neonatal health policy and funding in Hong Kong. 


\section{Introduction}

Extremely low birth weight (ELBW) infants (birth weight $<1000 \mathrm{~g}$ ) have high rates of mortality and morbidity. ${ }^{1,2}$ The survival of ELBW infants has improved significantly with the widespread use of exogenous surfactant agents, maternal steroids, mechanical ventilation, and advancements in neonatal technologies. ${ }^{1,3-7}$ The minimum age of viability is currently regarded as 21 to 22 weeks' gestation; accordingly, there have been scattered reports of survivors born at 21 to 22 weeks' estimated gestation., ${ }^{2,-11}$ Periviable birth is defined as delivery occurring from 20 weeks to 25 weeks 6 days of gestation. ${ }^{12}$ Notably, the rate of survival at 3 years for infants born at 22 weeks' gestation has been reported as approximately $36 \%$ in some centres. ${ }^{13}$ This study aimed to review mortality and morbidity of ELBW infants at a tertiary neonatal unit in Hong Kong.

\section{Methods}

Demographic and clinical data were analysed for consecutive neonates admitted to the neonatal unit of a university-affiliated teaching hospital (Prince of Wales Hospital) in Hong Kong between 1 January 2010 and 30 June 2017. During the study period, the Prince of Wales Hospital provided regional neonatal intensive care service for the Eastern New Territories of Hong Kong, with a catchment population of over 1.1 million (approximately 25\% were children aged $<12$ years). A standard data form was used for data abstraction by the investigators. All Clinical Management System records, inpatient records, and computerised laboratory data were examined. Numerical data were expressed as median (interquartile range) and compared by using the Mann-Whitney $U$ test; categorical data were compared by using the Chi squared test, or Fisher's exact test for data fields that contained $>20 \%$ cells with an expected count $<5$. Backward binary logistic regression was conducted on mortality; backward linear regressions were conducted on lengths of neonatal intensive care unit (NICU) stay and hospital stay for survivors. Corresponding Kaplan-Meier survival curves were constructed with survival distribution comparisons by log-rank test using SPSS (Windows version 20.0; IBM Corp, Armonk [NY], US). Two-tailed P values $<0.05$ were considered statistically significant.

\section{Results}

A total of 78 ELBW neonates were admitted to the NICU between 1 January 2010 and 30 June 2017; 16 of these neonates died (mortality 21\%) [Table 1]. For non-survivors and survivors, the median gestational ages were 24.1 and 26.2 weeks, respectively, and birth weights were 650 and $780 \mathrm{~g}$, respectively

\section{0年至2017年間香港極低出生體重嬰兒的死 亡率和發病率：單中心回顧 \\ 韓錦倫、廖沛鈞、周洎儀、曾燕靜、林鴻生、蘇景桓、 鄭昆瑜、梁國柱、王偉廉}

背景 : 極低出生體重嬰兒的死亡率和發病率高。本研究追溯並評估與 極低出生體重嬰兒死亡率和發病率相關的因素。

方法：對2010年至2017年間在第三級新生兒醫護單位出生的所有極低 出生體重嬰兒的圍產期人口統計學數據進行審查。

結果：非倖存的（佔總體 $21 \%$ ）和倖存的極低出生體重嬰兒的孕齡中 位數分別為 24.1 和 26.2 週, 出生體重中位數分別為 $650 \mathrm{~g}$ 和 $780 \mathrm{~g}(\mathrm{P}$ 值均 $<0.001$ ) 。迴歸分析顯示非倖存與孕齡較輕（每少1週的經調整 比值比 $=6.71 ; 95 \%$ 置信區間 $=1.73-26.00 ; \mathrm{P}=0.006$ ) 和第3或 4 級 腦室內出血（經調整比值比 $=29.23 ; 95 \%$ 置信區間 $=1.39-613.84$; $\mathrm{P}=0.030$ ）呈正相關；非倖存與支氣管肺發育不良呈負相關（經調 整比值比 $=0.01 ; 95 \%$ 置信區間 $=<0.001-0.23 ; \mathrm{P}=0.005)$; 新生兒 重症監護病房的生存時間與出現壞死性小腸結腸炎呈正相關（B系 數=89.60；95\%置信區間=43.86-135.34；P<0.001）。倖存者的住院 時間與出現壞死性小腸結腸炎（ $\mathrm{B}$ 係數 $=2.08 ; 95 \%$ 置信區間 $=0.43$ $3.73 ; \mathrm{P}=0.015)$ 和 1 分鐘Apgar評分低（B係數 $=-0.63 ; 95 \%$ 置信區 間 $=-1.04$ 至 $-0.22 ; \mathrm{P}=0.003)$ 呈正相關。

結論 : 極低出生體重嬰兒有顯著的死亡率和發病率。本研究顯示在妊 娠 23.6 週前或出生體重低於 $550 \mathrm{~g}$ 的極低出生體重嬰兒沒法倖存。出現 第3或4級腦室內出血單單與非㒓存相關。倖存者較大機會出現支氣管 肺發育不良, 而患有壞死性小腸結腸炎的倖存者更可能須在新生兒重 症監護病房和醫院留院較長時間。

$(\mathrm{P}<0.001)$. The median (interquartile range) of NICU stay before death was $2.5(2.0-11.5)$ days. The median durations of NICU stay and total hospital stay among survivors before discharge were 93.5 days and 4.1 months, respectively. Backward binary logistic regression analysis showed that non-survival was associated with lower gestational age (adjusted odds ratio $[\mathrm{aOR}]=6.71$ for every 1 -week decrease; $95 \%$ confidence interval $[95 \% \mathrm{CI}]=1.73-26.00 ; \mathrm{P}=0.006$ ) and grade 3 or 4 intraventricular haemorrhage $[\mathrm{IVH}](\mathrm{aOR}=29.23 ; 95 \% \mathrm{CI}=1.39-613.84 ; \mathrm{P}=0.030)$; non-survival was negatively associated with the presence of bronchopulmonary dysplasia (BPD) $[\mathrm{aOR}=0.01 ; 95 \% \mathrm{CI}=<0.001-0.23 ; \mathrm{P}=0.005)$, after adjustment for multiple births, caesarean section, birth weight, Apgar score at 1 minute, antenatal steroid administration, infant apnoea, necrotising enterocolitis (NEC), retinopathy of prematurity (ROP), and anaemia of prematurity in the first step of the regression analysis (Table 2). Backward linear regression revealed that the length of NICU stay for survivors was positively associated with the presence of NEC (B-coefficient=89.60; 95\% CI=43.86-135.34; $\mathrm{P}<0.001)$, after including gestational age, caesarean section, birth weight, Apgar score at 1 minute, 
TABLE I. Demographics and clinical factors of ELBW infants $(n=78)^{*}$

\begin{tabular}{|c|c|c|c|}
\hline & Non-survival $(n=16)$ & Survival $(n=62)$ & $P$ value \\
\hline Male sex & $10(62.5)$ & $32(51.6)$ & $0.436 \neq$ \\
\hline Gestational age, weeks & $24.1(24.0-24.3)$ & $26.2(25.0-27.7)$ & $<0.001 \dagger$ \\
\hline Multiple births & $7(43.8)$ & $13(21.0)$ & $0.105 \S$ \\
\hline Caesarean section & $3(18.8)$ & $25(40.3)$ & $0.109 \ddagger$ \\
\hline Birth weight, $\mathrm{kg}$ & $0.648(0.6-0.7)$ & $0.780(0.7-0.9)$ & $<0.001 \dagger$ \\
\hline \multicolumn{4}{|l|}{ Apgar score } \\
\hline $1 \mathrm{Min}$ & $4.0(3.0-6.0)$ & $5.0(4.0-7.0)$ & $0.010 \dagger$ \\
\hline 5 Min & $7.0(6.5-8.0)$ & $8.0(7.0-8.0)$ & $0.238 \dagger$ \\
\hline Maternal problems\| & $3(18.8)$ & $6(9.7)$ & $0.380 \S$ \\
\hline Antenatal steroid & $11(68.8)$ & $54(87.1)$ & $0.126 \S$ \\
\hline BPD & $2(12.5)$ & $50(80.6)$ & $<0.001 \ddagger$ \\
\hline Infant apnoea & $2(12.5)$ & $45(72.6)$ & $<0.001 \ddagger$ \\
\hline IVH & $12(75.0)$ & $30(48.4)$ & $0.057 \ddagger$ \\
\hline Grade 1 or 2 & $2(16.7)$ & $24(80.0)$ & $<0.001 \S$ \\
\hline Grade 3 or 4 & $10(83.3)$ & $6(20.0)$ & \\
\hline NEC & 0 & $16(25.8)$ & $0.032 \S$ \\
\hline ROP & $1(6.3)$ & $21(33.9)$ & $0.031 \S$ \\
\hline Blood stream infection & $2(12.5)$ & $14(22.6)$ & $0.501 \S$ \\
\hline Anaemia of prematurity & $7(43.8)$ & $55(88.7)$ & $<0.001 \S$ \\
\hline NICU stay, days & $2.5(2.0-11.5)$ & $93.5(79.0-125.0)$ & $<0.001 \dagger$ \\
\hline Discharge age, months & N/A & $4.1(3.6-5.3)$ & N/A \\
\hline
\end{tabular}

Abbreviations: BPD = bronchopulmonary dysplasia; ELBW = extremely low birth weight; IVH = intraventricular haemorrhage; N/A = not applicable; NEC = necrotising enterocolitis; NICU = neonatal intensive care unit; ROP = retinopathy of prematurity

* Data are shown as No. (\%) of subjects, or median (interquartile range)

+ Mann-Whitney $U$ test

$\neq$ Chi squared test

$\S$ Fisher's exact test

॥ Maternal problems included sepsis, diabetes, and cervical incontinence

and blood stream infection in the first step of the regression analysis (Table 3 ). The length of hospital stay was positively associated with presence of NEC (B-coefficient $=2.08 ; 95 \% \quad \mathrm{CI}=0.43-3.73 ; \mathrm{P}=0.015$ ), but negatively associated with Apgar score at 1 minute (B-coefficient $=-0.63 ; 95 \% \mathrm{CI}=-1.04$ to -0.22 ; $\mathrm{P}=0.003)$, after including gestational age, birth weight, Apgar score at 1 minute, and Apgar score at 5 minute in the first step of the regression analysis (Table 3).

Survival curves were constructed for gestational age (Fig 1) and birth weight (Fig 2). Median KaplanMeier survival estimates for gestational ages $<24,24$, and 26 weeks were $43 \%, 52 \%$, and $92 \%$, respectively (no death records were available for other groups), during the period of postnatal NICU stay before discharge; importantly, their survival distributions were significantly different $\left(x^{2}=31.1 ; \quad \mathrm{P}<0.001\right)$. Median Kaplan-Meier survival estimates for birth weights $<600 \mathrm{~g}, 600$ to $699 \mathrm{~g}$, and 700 to $799 \mathrm{~g}$ were
$55 \%, 63 \%$, and $81 \%$, respectively (no death records were available for other groups); their survival distributions were significantly different $\left(X^{2}=13.9\right.$; $\mathrm{P}=0.008)$ [Fig 2].

\section{Discussion}

Extremely low birth weight infants, especially those born at periviable gestations of 22 to 23 weeks, exhibit significantly higher mortality. In this cohort of ELBW infants, we confirmed two independent factors associated with ELBW non-survival: gestation age below 24 weeks and the presence of grade 3 or 4 IVH. Although not specifically analysed in this series, congenital anomalies did not appear to be a pertinent risk factor influencing survival among ELBW infants. Among infants in the non-survival group, the median time until death was 2.5 days after birth; in our series, no survival was observed for ELBW infants whose birth occurred prior to 23.6 
weeks or who exhibited birth weight of $<550 \mathrm{~g}$. These local data are expected to be useful in counselling pregnant women who are at risk for the delivery of ELBW infants. Non-survival was associated with an increased aOR of 6.7 for every 1-week decrease in gestation.

In addition to perinatal mortality, long-term survival was also low. A previous report stated that first-year survival was $15.5 \%$ for infants whose birth weight was $<500$ g. ${ }^{14}$ Infants with ELBW are more susceptible to all complications of prematurity, both during the immediate neonatal period and after discharge from the nursery. A study by the Eunice Kennedy Shriver National Institute of Child Health and Human Development Neonatal Research Network, ${ }^{15}$ undertaken to relate other known risk factors with the likelihood of survival and impairment, reported that $83 \%$ of infants born at 22 to 25 weeks' gestation received intensive care involving mechanical ventilation. Of the infants whose outcomes were known at 18 to 22 months, $49 \%$ died, $61 \%$ died or had profound impairment, and $73 \%$ died or had impairment.

Additional reports have suggested that other factors should be considered, in combination with gestational age, when determining the likelihood of favourable outcomes with intensive care. ${ }^{15-19}$ According to the data from a 2011 cohort study, infants born at 23 to 25 weeks' gestation who received antenatal exposure to corticosteroids exhibited a lower rate of mortality and complications, compared with infants who did not have such exposure. ${ }^{16}$ Recently, chorioamnionitis was linked to preterm birth and neonatal infection. In a longitudinal observational study that included 2390 extremely preterm infants (gestational age $<27$ weeks), Pappas et $\mathrm{al}^{20}$ reported that antenatal exposure to chorioamnionitis appeared to increase the odds of cognitive impairment, as well as death/ neurodevelopmental impairment.

Survival occurred in $79 \%$ of ELBW infants at our centre. Extremely low birth weight survivors exhibited significant morbidity. Our series showed that BPD, severe IVH, NEC, and ROP were present in $81 \%, 20 \%, 26 \%$, and $34 \%$ of survivors, respectively. Notably, the survivors experienced long stays in the NICU and hospital prior to discharge. Necrotising enterocolitis is particularly associated with long stays in the NICU and hospital. The sequelae of low birth weight have been well-studied, but less information is available regarding sequelae of ELBW. ${ }^{21}$ Low birth weight is generally closely associated with fetal and perinatal mortality and morbidity, inhibited growth and cognitive development, and a risk of chronic diseases later in life. At the population level, the proportion of infants with low birth weight is an indicator of a multifaceted public health problem that includes long-term maternal malnutrition,
TABLE 2. Logistic regression analysis of mortality $(n=78)$

\begin{tabular}{lccc}
\hline & $\begin{array}{c}\text { Adjusted } \\
\text { odds ratio }\end{array}$ & $\begin{array}{c}95 \% \\
\text { Confidence } \\
\text { interval }\end{array}$ & P value \\
\hline Gestational age & 0.15 & $0.04-0.58$ & 0.006 \\
BPD & 0.01 & $<0.001-0.23$ & 0.005 \\
IVH grade 3 or 4 & 29.23 & $1.39-613.84$ & 0.030 \\
\hline
\end{tabular}

Abbreviations: BPD = bronchopulmonary dysplasia; IVH = intraventricular haemorrhage

TABLE 3. Linear regression analysis of length of NICU or hospital stay for survivors $(n=62)$

\begin{tabular}{lccc}
\hline & B & $\begin{array}{c}95 \% \\
\text { Confidence } \\
\text { interval }\end{array}$ & P value \\
\hline $\begin{array}{l}\text { NICU stay } \\
\text { NEC }\end{array}$ & 89.60 & $43.86-135.34$ & $<0.001$ \\
\hline $\begin{array}{l}\text { Hospital stay } \\
\text { Apgar score at 1 min }\end{array}$ & -0.63 & -1.04 to -0.22 & 0.003 \\
\hline NEC & 2.08 & 0.43 to 3.73 & 0.015 \\
\hline
\end{tabular}

Abbreviations: NEC = necrotising enterocolitis; NICU = neonatal intensive care unit

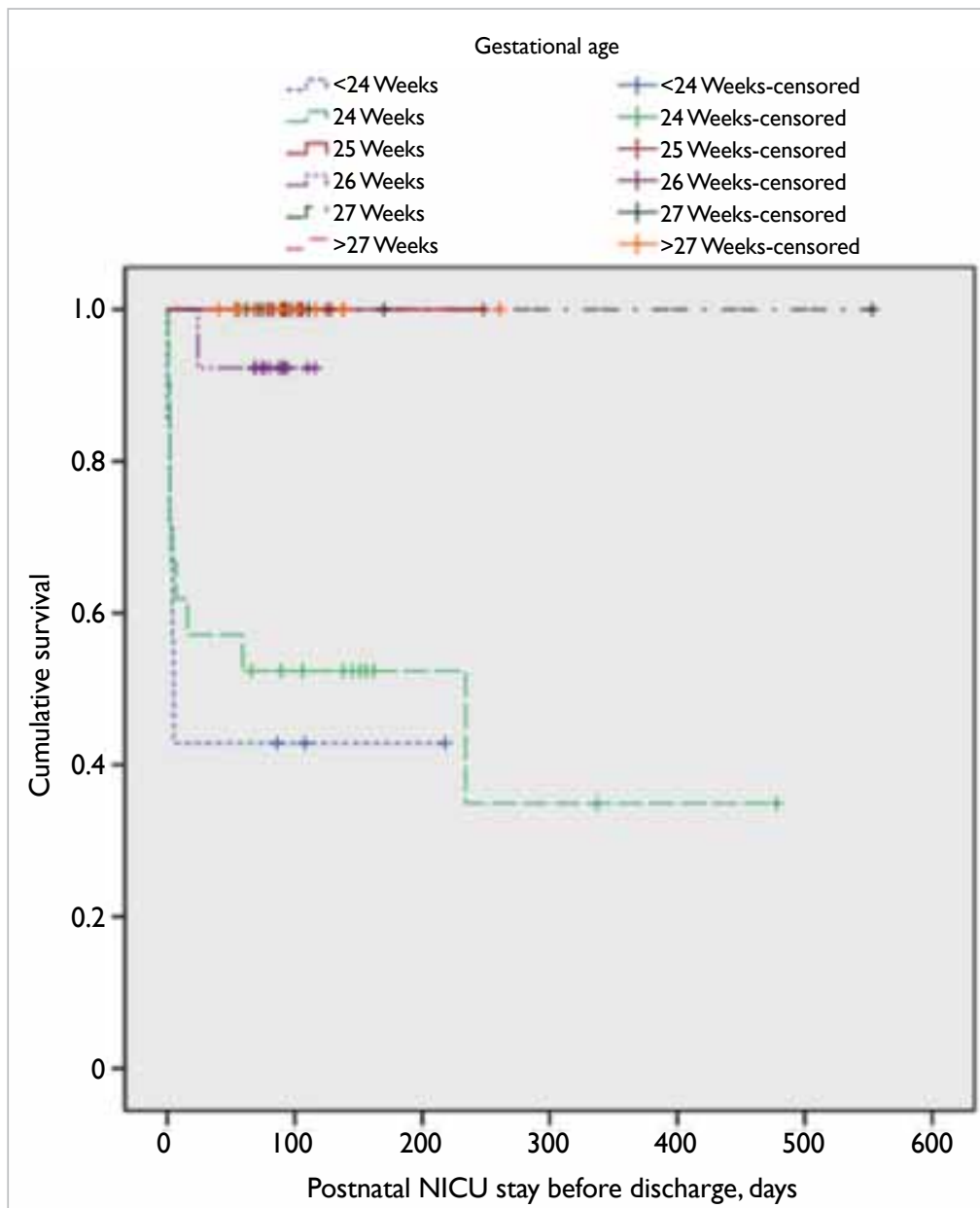

FIG I. Kaplan-Meier survival curve according to gestational age $(n=78)$

Abbreviation: $\mathrm{NICU}=$ neonatal intensive care unit 


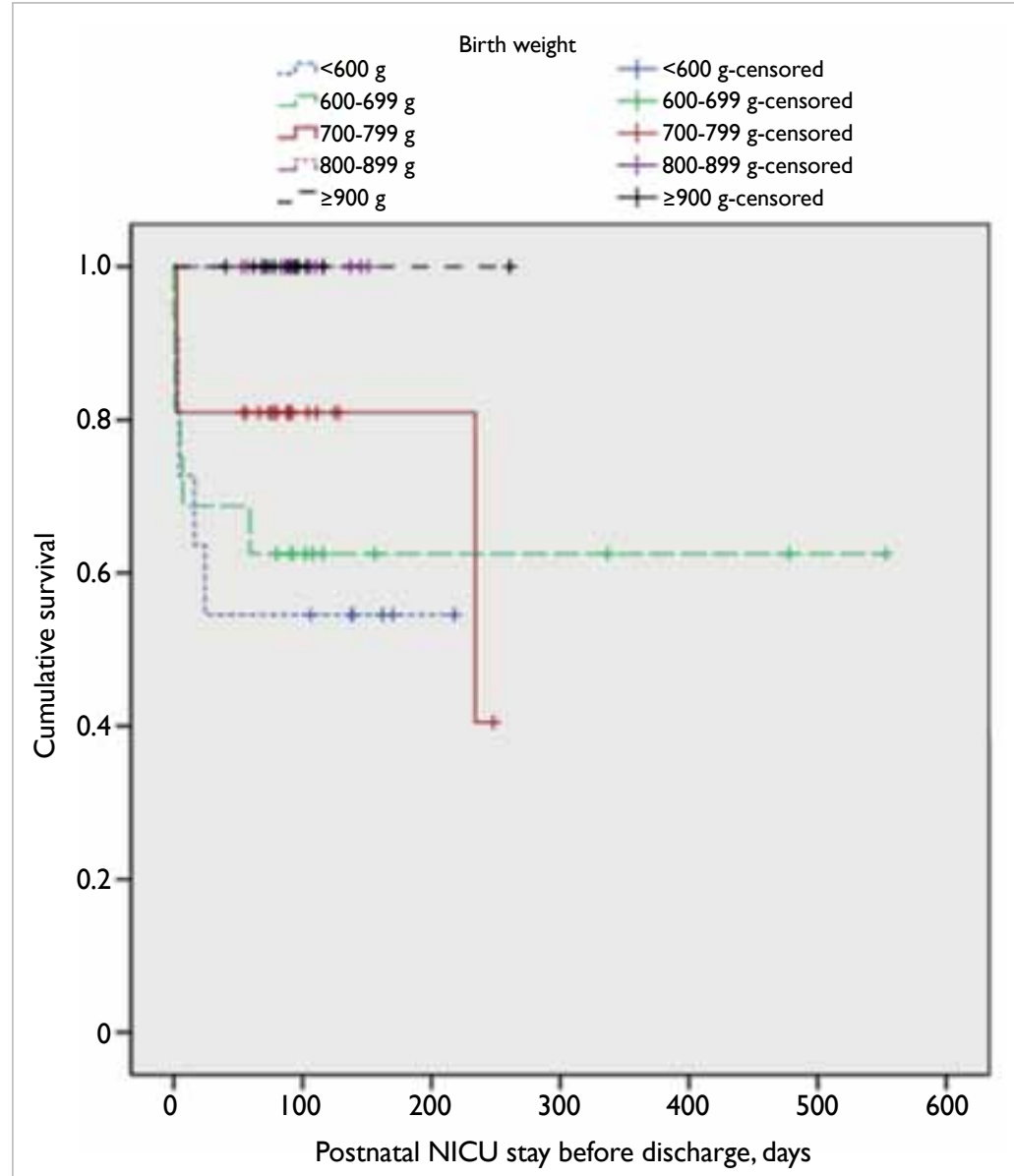

FIG 2. Kaplan-Meier survival curve according to birth weight $(n=78)$

Abbreviation: NICU = neonatal intensive care unit infants with grade $3 \mathrm{IVH}$ exhibit significant cognitive impairment, and up to $90 \%$ of infants with grade 4 IVH exhibit major neurologic sequelae, requiring lifetime care. Notably, a study of 1064 infants born at $\leq 28$ weeks' gestation found that, unless it was accompanied or followed by a white matter lesion, low-grade IVH was associated with a modest to nonexistent risk of adverse developmental outcomes during infancy. ${ }^{29}$

The outcomes of ELBW infants are evolving as therapy and supportive care continue to change. ${ }^{1}$ Clinical focus should be placed on the prevention of premature births, as well as equipping NICU staff and facilities with the necessary skills and resources, respectively, to implement evidence-based interventions that improve the survival of ELBW infants. Efforts to minimise injury, preserve growth, and identify interventions focused on antioxidant and anti-inflammatory pathways are currently being evaluated. Thus, treatment and prevention of longterm deficits must be developed in the context of an evolving target. Ensuring health in cases of extreme prematurity ( $\leq 23$ weeks' gestation) is extremely difficult. ${ }^{2}$ Most centres do not have minimum birth weight criteria for resuscitation; often, a "trial of life" may be discussed with the parents before the birth of the infant so that the infant can be resuscitated and evaluated for viability after birth. Viability is the term frequently used to indicate the potential for a fetus to be liveborn and capable of surviving to a specified endpoint (eg, a designated time, attainment of a certain age or landmark event, admission to the NICU, or discharge from the hospital). Many institutions have generated centrespecific data regarding the probability of survival to aid in discussions with families prior to delivery. Discussions regarding the withdrawal of treatment or support are often necessary when the family and medical team agree that the continuation of medical treatment is not in the infant's best interests. Naturally, these circumstances involve numerous ethical, moral, and legal issues; they may generate more questions than answers. Therefore, each centre caring for ELBW infants must carefully follow and analyse their particular survival statistics, in order to better inform and guide parents concerning the outcomes and prognoses of these periviable infants.

\section{Author contributions}

Concept or design: KL Hon, S Liu, JCY Chow.

Acquisition of data: KL Hon, S Liu, JCY Chow.

Analysis and interpretation of data: KL Hon, KYC Tsang.

Drafting of the article: KL Hon, Y Cheng, AKC Leung.

Critical revision for important intellectual content: All authors.

\section{Declaration}

As an editor of the journal, KL Hon was not involved in the peer 
review of the article. All authors have disclosed no conflicts of interest. All authors had full access to the data, contributed to the study, approved the final version for publication, and take responsibility for its accuracy and integrity.

\section{Funding/support}

This research received no specific grant from any funding agency in the public, commercial, or not-for-profit sectors.

\section{Ethical approval}

Ethics approval for this study was obtained from the Clinical Research Ethics Committee of The Chinese University of Hong Kong.

\section{References}

1. Glass HC, Costarino AT, Stayer SA, Brett CM, Cladis F, Davis PJ. Outcomes for extremely premature infants. Anesth Analg 2015;120:1337-51.

2. Blencowe H, Cousens S, Chou D, et al. Born too soon: the global epidemiology of 15 million preterm births. Reprod Health 2013;(10 Suppl 1):S2.

3. Anderson JG, Baer RJ, Partridge JC, et al. Survival and major morbidity of extremely preterm infants: a populationbased study. Pediatrics 2016;138:e20154434.

4. García-Muñoz Rodrigo F, García-Alix Pérez A, García Hernández JA, Figueras Aloy J; Grupo SEN1500. Morbidity and mortality in newborns at the limit of viability in Spain: a population-based study. [in Spanish]. An Pediatr (Barc) 2014;80:348-56.

5. Crane JM, Magee LA, Lee T, et al. Maternal and perinatal outcomes of pregnancies delivered at 23 weeks' gestation. J Obstet Gynaecol Can 2015;37:214-24.

6. Jarjour IT. Neurodevelopmental outcome after extreme prematurity: a review of the literature. Pediatr Neurol 2015;52:143-52.

7. Partridge JC, Robertson KR, Rogers EE, Landman GO, Allen AJ, Caughey AB. Resuscitation of neonates at 23 weeks' gestational age: a cost-effectiveness analysis. J Matern Fetal Neonatal Med 2015;28:121-30.

8. Tyson JE, Younes N, Verter J, Wright LL. Viability, morbidity, and resource use among newborns of 501- to 800 -g birth weight. National Institute of Child Health and Human Development Neonatal Research Network. JAMA 1996;276:1645-51.

9. Berger TM, Bernet V, El Aama S, et al. Perinatal care at the limit of viability between 22 and 26 completed weeks of gestation in Switzerland. 2011 revision of the Swiss recommendations. Swiss Med Wkly 2011;141:w13280.

10. Obstetric care consensus No. 4: periviable birth [editorial]. Obstet Gynecol 2016;127:e157-69.

11. Obstetric care consensus No. 4 summary: periviable birth [editorial]. Obstet Gynecol 2016;127:1184-6.

12. American College of Obstetricians and Gynecologists, Society for Maternal-Fetal Medicine. Obstetric care consensus No. 6: periviable birth. Obstet Gynecol 2017;130:e187-99.

13. Ishii N, Kono $\mathrm{Y}$, Yonemoto N, et al. Outcomes of infants born at 22 and 23 weeks' gestation. Pediatrics 2013;132:6271.

14. MacDorman MF, Hoyert DL, Mathews TJ. Recent declines in infant mortality in the United States, 2005-2011. NCHS Data Brief 2013;120:1-8.

15. Tyson JE, Parikh NA, Langer J, Green C, Higgins RD, National Institute of Child Health and Human Development Neonatal Research Network. Intensive care for extreme prematurity-moving beyond gestational age. N Engl J Med 2008;358:1672-81.

16. Carlo WA, McDonald SA, Fanaroff AA, et al. Association of antenatal corticosteroids with mortality and neurodevelopmental outcomes among infants born at 22 to 25 weeks' gestation. JAMA 2011;306:2348-58.

17. Lee HC, Green C, Hintz SR, et al. Prediction of death for extremely premature infants in a population-based cohort. Pediatrics 2010;126:e644-50.

18. Younge N, Goldstein RF, Bann CM, et al. Survival and neurodevelopmental outcomes among periviable infants. N Engl J Med 2017;376:617-28.

19. Patel RM, Kandefer S, Walsh MC, et al. Causes and timing of death in extremely premature infants from 2000 through 2011. N Engl J Med 2015;372:331-40.

20. Pappas A, Kendrick DE, Shankaran S, et al. Chorioamnionitis and early childhood outcomes among extremely low-gestational-age neonates. JAMA Pediatr 2014;168:137-47.

21. Stevens-Simon C, Orleans M. Low-birthweight prevention programs: the enigma of failure. Birth 1999;26:184-91.

22. EXPRESS Group, Fellman V, Hellström-Westas L, et al. One-year survival of extremely preterm infants after active perinatal care in Sweden. JAMA 2009;301:2225-33.

23. Jobe AH. The new bronchopulmonary dysplasia. Curr Opin Pediatr 2011;23:167-72.

24. Bhandari A, McGrath-Morrow S. Long-term pulmonary outcomes of patients with bronchopulmonary dysplasia. Semin Perinatol 2013;37:132-7.

25. Gordon PV, Swanson JR. Necrotizing enterocolitis is one disease with many origins and potential means of prevention. Pathophysiology 2014;21:13-9.

26. Torrazza RM, Li N, Neu J. Decoding the enigma of necrotizing enterocolitis in premature infants. Pathophysiology 2014;21:21-7.

27. Berman L, Moss RL. Necrotizing enterocolitis: an update. Semin Fetal Neonatal Med 2011;16:145-50.

28. Merhar SL, Tabangin ME, Meinzen-Derr J, Schibler KR. Grade and laterality of intraventricular haemorrhage to predict 18-22 month neurodevelopmental outcomes in extremely low birthweight infants. Acta Paediatr 2012;101:414-8.

29. O'Shea TM, Allred EN, Kuban KC, et al. Intraventricular hemorrhage and developmental outcomes at 24 months of age in extremely preterm infants. J Child Neurol 2012;27:22-9. 